\title{
Exploration of Natural Playgrounds in Urban Parks: Promoting Children's Health
}

\author{
Kaidi Zuo ${ }^{1}$, Lihua Wei ${ }^{1,}$, Yanguo Cong ${ }^{2}$ \\ ${ }^{1}$ School of Architecture, South China University of Technology, Guangzhou, China \\ ${ }^{2}$ College of Forestry and Landscape Architecture, South China Agricultural University, Guangzhou, China \\ Email address: \\ 1423933792@qq.com (Kaidi Zuo),weilh@scut.edu.cn (Lihua Wei),64189344@qq.com (Yanguo Cong) \\ ${ }^{*}$ Corresponding author
}

\section{To cite this article:}

Kaidi Zuo, Lihua Wei, Yanguo Cong. Exploration of Natural Playgrounds in Urban Parks: Promoting Children's Health. Urban and Regional Planning. Vol. 5, No. 4, 2020, pp. 122-131. doi: 10.11648/j.urp.20200504.14

Received: November 11, 2020; Accepted: December 1, 2020; Published: December 16, 2020

\begin{abstract}
Children's health includes physiological, psychological, cognitive, behavioral and other aspects of health. Playing in nature has been demonstrated to have irreplaceable benefits for children's health. However, the urban built-up environment devours the natural play space and aggravates children's problems. Since the 1990s, people have gradually realized the importance of nature and play, thus began to explore the natural children's playground. The COVID-19 pandemic also makes people pay greater attention to the natural and healthy living environment. The urban park is an important place for children to play freely. It is of great significance to explore the natural design of its playground. Starting from the connotation and function of nature, games and playgrounds, this paper analyzes children's preference for playgrounds. In addition, combined with the previous researches, five thoughts on the planning and design of natural playgrounds in urban parks are summarized: (1) The natural environment should be accessible and approachable; (2) The original natural objects and the natural products are suitable to coexist; (3) The undulating terrain can be combined with the flat grassland; (4) The dynamic and diversity of natural elements is very important; (5) The balance between safety and adventure is also needed. Finally, it is proposed that children's choice priority and use characteristics of various play elements can be further studied to guide planning and design more accurately.
\end{abstract}

Keywords: Natural Playgrounds, Urban Parks, Children's Health

\section{Introduction}

Childhood is a critical period for physical, mental and cognitive development. Children are more deeply affected by their surroundings than people of other ages [1]. The World Health Organization defines children's health as the overall health including physical, mental, intellectual, social, behavioral and emotional [2]. The relationship between play, nature and children's health has been fully discussed in the fields of biology, medicine, psychology and education, which will be explained deeply in part 2.2.

Human beings are from nature and have a natural affinity to nature. Many researchers have found that adults always emphasize some natural elements when they recall their favorite playing environment in childhood. For instance, Robert Pyle, a professor from the Yale School of Forestry \& Environmental Studies, surveyed the places where people used to play. Most people described spaces with water, trees or undeveloped parks. The common characteristics of these places are "accessibility, wildness and secrecy". There, children's bodies are integrated with nature in a free posture, bringing precious childhood memories to children [3].

Unfortunately, these spaces have changed or no longer exist due to the urbanization process in the past few decades. The monotonous experience brought by the standard playing space of "venue \& made-up articles" has replaced the diverse challenges of natural informal activities [4]. Children can only be limited to procedural activities: waiting in line, going up, drilling through, sliding down, and re-queuing [5]. In these "purified" spaces, children's play becomes a kind of in-situ movement carried out by moving local limbs [6]. The opportunities for free play, choice and exploration are greatly reduced, the complete physical playing experience is lost, and the chances for mutual assistance and communication with peers are limited. Under these circumstances, more and 
more children suffer from "nature-deficit disorder" and "biophobia" [7-8], which lead to many physical and mental problems, such as obesity, sensory degeneration, anxiety and depression, distractibility, lack of empathy and so on.

In the past 30 years, people have gradually realized the importance of unrestricted play in challenging natural environment for children's healthy development, as well as the fact that the natural environment is swallowed up in the city. Therefore, the trend of integrating nature into children's outdoor play space has been concerned by all walks of life [9]. In 1996, the United Nations put forward the concept of "child-friendly city"(CFC), in which "children live in a space where they can get access to green plants and have ground and facilities for them to play happily" [10]. Since 2002, the British government has launched activities such as "starting from the park" and "going to the green space", and many countries in northern Europe have established "forest schools" [11]. With the outbreak of the COVID-19 pandemic in early 2020, people's demand for healthful living environment has been enlarged, which further highlights the urgent need to provide children with natural playgrounds.

Urban parks possess the characteristics of public welfare, openness and semi-naturalness. As a kind of green infrastructure for people to carry out outdoor activities, the high quality of urban parks plays an important role in maintaining the overall health of residents [12]. Its significance does not only stay in visual performance and market function, but also needs to give full scope to its social value [13]. The children's playground in the park is an essential place to undertake children's activities. It should provide children with ample opportunities to contact with nature, play freely and communicate smoothly.

Since the 21 st century, researchers in the fields of architecture, urban planning and landscape in Europe, North America, Japan and other countries and regions have gradually increased their studies on natural playgrounds. Designers are also seeking to abandon the paradigm of conventional standardization and turn to natural design methods in practice, such as the Ian Potter Children's WILD PLAY Garden in Sydney's Centennial Parklands, the Diana Princess of Wales Memorial Playground in London and so on. The main aspects involved in the studies include: (1) people's cognition of natural playgrounds [14]; (2) design methods of natural playgrounds (including design principles, spatial layout, supply of natural elements and materials $[9,15,16]$, etc.); (3) operation and management of natural playgrounds (including supporting policies, organization subjects, children's participation, and maintenance [17-19], etc.); (4) design cases analysis [20]; (5) children's behavior in natural playgrounds [21], etc. Generally speaking, the research on children's natural playgrounds in urban parks is still in the stage of continuous exploration. Therefore, how to integrate the diverse elements of nature into urban park playgrounds is a key issue that needs to be further explored.

\section{Interpretation of "Nature" and "Play"}

\subsection{The Concept Connotation}

What needs to be considered first is the category of "nature". Researchers have given multiple interpretations from the broad to the narrow sense (Table 1) [22-25]. For urban parks and their playgrounds, nature can be regarded as the part where people can experience (wild) organic environment intimately. While, what is more important is what kind of interaction with natural materials and biological elements these places can provide for children.

Table 1. Analyses of the concept "nature".

\begin{tabular}{|c|c|c|c|}
\hline Source of definition & Understanding of "nature" & Interpretation of connotation & Scale \\
\hline "Back-to-Nature" movement & A state of being wild and uncontaminated & A rather radical concept of nature & \\
\hline Broad and inclusive definition & $\begin{array}{l}\text { The environment in which most ecosystem } \\
\text { processes exist }\end{array}$ & $\begin{array}{l}\text { Including habitats ranging from wilderness } \\
\text { areas to gardens }\end{array}$ & Broad sense \\
\hline $\begin{array}{l}\text { Advocators of the "New } \\
\text { Naturalism" }\end{array}$ & $\begin{array}{l}\text { Wherever humans experience meaningful } \\
\text { intimacy with other species }\end{array}$ & $\begin{array}{l}\text { Focusing on people's perception of the } \\
\text { environment }\end{array}$ & $\begin{array}{l}\downarrow \\
\text { Narrow sense }\end{array}$ \\
\hline $\begin{array}{l}\text { Research on the benefits of } \\
\text { nature to children }\end{array}$ & Any space with green plants & $\begin{array}{l}\text { Elementary naturalization in urban } \\
\text { environment }\end{array}$ & \\
\hline
\end{tabular}

Then, what is "play"? At the end of the 19th century, the early classical theory explained the causes of play from the perspective of biology. It mainly includes the theory of surplus energy, entertainment and relaxation, race repetition, and life preparation [26], all of which are intended to show that play is the promotion of human innate instinct and desire. In the 20th century, the rise of psychoanalysis school and cognitive development theory promoted the formation of contemporary theory of play [27-28]. From the perspective of psychology and sociology, it expresses that the playing activities as a social person include subjective initiative and sociality. Generally speaking, "play" is a type of behavior with pleasure under the condition of health and no pressure. It is spontaneous and voluntary without teaching, often with imagination and simulation, and the experience during the playing process is more important than the purpose and result.

"Nature play" is defined by the Children \& Nature Network organization as outdoor free play in natural areas. It combines children's experience of happiness and self-guidance in natural places, with imagination, constructive, rich senses and cooperation.

\subsection{The Significance of Playing in Nature for Children's Overall Health}

More and more theories and empirical evidences show that nature and play bring a lot of physiological, psychological, cognitive and social benefits to human beings. 


\subsubsection{Promote Physical Growth and Physiological Health}

Tracing back to history, human beings have evolved from nature. Nature has endowed human beings with all their genes and inherited them from generation to generation [29]. Under the guidance of these "nature genes", people obtain living resources from nature, and fight against natural adverse factors through contact with "ancestral" microbiota in the natural environment, so as to obtain comprehensive and systematic immune competence [30]. Edward O. Wilson, an American social biologist, called this phenomenon the "biophilia hypothesis" [8]. Studies in the field of nature neuroscience and clinical medicine have further explained the mechanism of nature's action on human beings. When people are in a natural environment matched with their habitat preference, some active ingredients in nature, such as negative air ions, phytoncides and mycobacterium vaccae, make the human body secrete some neurochemicals, and also act on the immune system and cardiovascular function. This can make people produce positive physiological reactions, which can prevent respiratory diseases, normalize blood pressure and blood glucose, and relieve migraines [31], etc. The more people contact with nature, the less disease they suffer from, and the faster they recover [32].

In addition, play with physical activity characteristics can also promote physical growth. Children climb, jump, run, climb, all parts of the body get exercise. Moreover, Fjørtoft (2004) found that compared with playing artificial facilities, playing in natural places can significantly promote children's body balance and motor coordination [33].

\subsubsection{Dispel Anxiety and Vent Attack}

Erik H. Erikson, an American developmental psychologist, has constructed the theory of eight stages of personality development, pointing out that each stage has different development tasks and contradictions. These contradictions bring anxiety to children, while the smooth resolution of contradictions is the premise of healthy personality development [34]. Therefore, children need "transitional association" to prevent anxiety and help them control their emotions [35]. Roger S. Ulrich put forward the "stress recovery theory", which holds that human's response to the natural environment without threat is unconscious and hardly needs to be processed by cognition. Therefore, when people are in it, they will feel relaxed, so that they can quickly recover from the pressure, and can also inhibit impulse and reduce violence [36-37].

While, play is to satisfy the child's desire by compensation, so that he/she can control the ideas and impulses that lead to anxiety, and even internalize the quality of management anxiety into self-structure, then smoothly transition from one stage to the next [34]. If this process is stopped, the child may not be able to adapt to intense stress and produce abnormal forms of anxiety release, such as masturbation or daydreaming. Donald Winnicott pointed out that aggression is innate and is the core of emotional development, but the form of aggression changes with the environment in which children grow up. The promotive environment enables children to express their original aggressiveness in playing, so that children's aggression will be alleviated and will not be displayed in a destructive antisocial way [35].

\subsubsection{Cultivate Cognitive and Communicative Abilities}

Playing in nature can also promote children's cognitive and social development ability. Among them, "attention restoration theory" proposed by Rachel Kaplan and Stephen Kaplan and relevant investigations have proved that contact with nature can relieve fatigue, improve and restore concentration, and treat attention deficit disorder [38], etc. In addition, play in the natural environment also help to improve observation ability, enhance imagination, creativity, exploratory and divergent thinking, cultivate self-discipline ability, stimulate the desire for autonomous learning, improve academic performance, communicate with other children more easily and freely, and develop aesthetics [39], etc. At the same time, being in nature is also a process of feeling the growth and significance of life, which can trigger children's perceptual cognition, and learn to care for life. Frequent contact with nature will also promote the formation of children's environmental ethics and bring positive environmental protection values and behavior development [32]. (Figure 1)

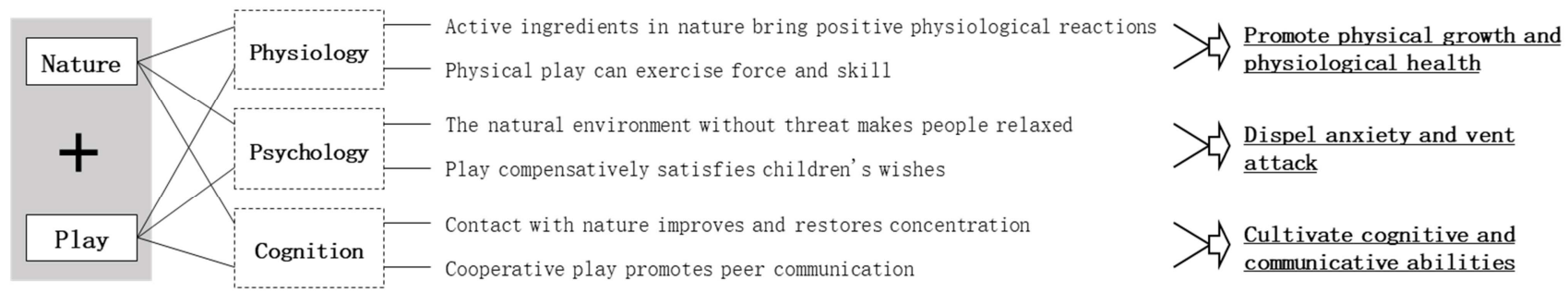

Figure 1. The mechanism of nature and play on children's health.

\section{Urban Parks and Their Playgrounds}

\subsection{The Significance of Playgrounds: Shaping Children's Behavior of Play}

For the function of environment, on the one hand, it depends on the characteristics of the environment itself (e. g., large rocks provide climbing opportunities, while bushes provide chances for hide and seek and fantasy pretending, etc.), on the other hand, it is affected by individual attributes and behaviors (e. g., children may choose to run or jump along the path, while older adults prefer to walk slowly). The 
supply of environment is what it "invites" individuals to do, and depends on one's will, strength, and skills [21], etc. The design of playgrounds will affect the frequency, type, duration and quality of children's activities [40]. Helen Woolley, a researcher at the University of Sheffield, pointed out that a children's playground is not only a place to stimulate different activities, but also the development theme of environmental perception, physical exercise, communication and cooperation, development and creation, and cognitive education [41].

\subsection{Children's Preference for Play Environment: Challenging Semi-Natural Playgrounds}

Scholars from all over the world have studied "what kind of environment children want to play in" by using the methods of children's painting and discussion, picture-based questionnaire interview, tracking observation and walk-along interview [14, 42, 43, 44]. It is generally found that children express obvious thirst for nature, physical activity and adventure. For the natural play field, the acceptance of simple and clear environment with certain play guidance is higher than that of pure natural environment which is difficult to identify.

Boys and girls all want to participate in activities such as climbing, jumping, skating, swinging, responding to music, playing hide and seek and exploring, and almost all ideas are related to nature, including descriptions of natural scenes (forests, grasslands, rivers, rocks, jungles, etc.), weather details (storms, sun, rain, etc.), and various plants (climbing and hiding trees, green leaves / shade, flowers, etc.) [42]. Nature has become the top priority of children's "perfect" parks, and the acceptance of natural playgrounds among children is higher than that of equipment playgrounds, while there is no place for straight lines or asphalt roads [44].

The natural playground model preferred by children is based on natural elements such as water, sand and stone, undulating terrain, diverse animals and plants, with simple and clear content and easy to identify and play. For the highly naturalized playground, some children are reluctant to choose because of fear of forest and insects [14].

One of the most important features that most children (no matter boys or girls) repeatedly mention is the large, challenging adventure playground that can be climbed and shaken. In addition to "high" and "large", children also specify the special facilities they want, including long slides, various types of large swings (e. g., tires and $360^{\circ}$ swings), flying foxes, and climbing poles [44], etc. However, for the single function of the slide castle combination, the researchers found that children played for less than 5 minutes in a row [43].

\subsection{Common Problems in Urban Park Playgrounds}

Over designed and inaccessible nature deprives children of the opportunity to experience life closely. In urban parks, it is rare to see unregulated land with free growth of flowers and plants. Instead, a large number of enclosed and pruned artificial landscapes are provided, and people are excluded by using "warm tips" signs like "Do not step on the lawn", "It is forbidden to pick flowers, branches, and shrubs", etc.

The patterned equipment limits children's nature of free running and creative play. Many of the playgrounds in modern cities are provided with standardized facilities based on discipline, such as plastic slide combination. Designers build equipment according to a relatively fixed method of use, so that children follow one or a few simple paths to complete the activity. Children's play experience has changed from self-exploring pleasure to mechanically operated cycle [6].

The over protection of children cannot create more opportunities for adventure. Taking risks is the basis for kids to explore and understand the world [45]. Children need to participate in activities with certain risks in the process of growing up. However, the construction concept of absolutely safe playground limits designers to providing specific facilities for safe play, thus losing the potential of exploring playground for children's adventure activities. (Figure 2)

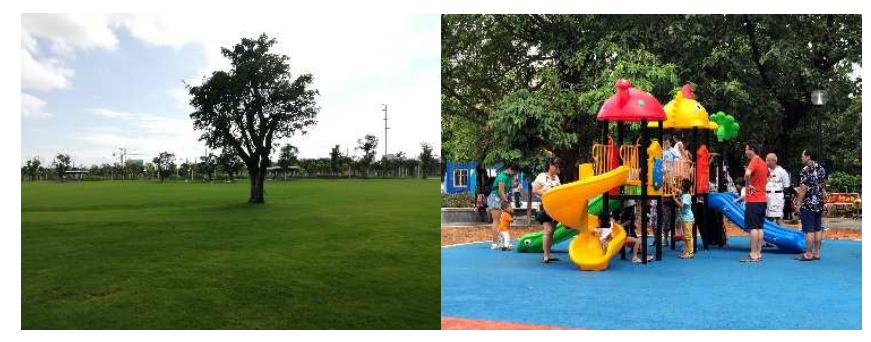

Figure 2. Artificial nature and model play facilities in urban parks.

\subsection{The Naturalization Turn of Urban Park Playgrounds}

With the deepening understanding of the positive role of nature and play, designers began to attach importance to the combination of children's playground and nature, thus put forward the concept of "natural playground".

\subsubsection{The Concept, Definition, Types and Characteristics of Natural Playgrounds}

Different from the standard metal and plastic playgrounds, the concept of natural playgrounds is to accommodate the surrounding landscape and vegetation to create a "natural" atmosphere that integrates nature with outdoor play. And emphasize the participation of children, through the five senses to harvest natural happiness. However, unlike the pure natural environment with uncontrollable risks for children, the natural playground is a simulated natural space that not only ensures certain safety, but also has natural wild interest and moderate risk. It presents a "reduced version" of the natural environment in children's eyes [46], so that they can consciously integrate into nature and experience growth.

"The Natural Start Organization" describes the natural playground as the place where natural elements are provided, and must be allowed to operate on these elements, that is, children can freely carry out activities such as digging, collecting, climbing, building and hiding [17]. There are three basic forms: (1) One is to use only natural elements, such as water, soil, rocks, trees, flowers and insects, etc., to 
create an experience similar to the real wild nature; (2) The other is to use materials such as wood and concrete to create a space that is integrated with or similar to the common objects in nature; (3) There is also a combination of the two types, from a completely natural environment to a natural playground with a mixture of natural elements and facilities.

Traditional facilities let children know what they should play and how to play, while natural playgrounds usually provide more open uses, using terrain and vegetation to stimulate and create opportunities for spontaneous interaction and different types of play. They are also designed for more physical challenges than traditional playgrounds [47]. Professor Sandseter (2009) believes that children will seek adventure play in any environment, but compared with traditional playgrounds, natural playgrounds have not only higher risk, but also less restrictions, providing more opportunities for children to obtain exciting experiences. Therefore, a list of environmental affordability is proposed, including climbable characteristics, jump-down-off-able features, balanced mobility, scalability, smooth surfaces, and hazardous elements [48].

\subsubsection{The Characteristics of Children's Activities in Natural Playgrounds}

There is no lack of empirical research confirmed the important role of natural playgrounds to some extent: providing children with a wide range of play and learning opportunities that cannot be obtained in other playgrounds. For example, Gregor Torkar and Aljoša Rejc (2017) asked 25 preschool children in a small town in Northwest Slovenia to play in a traditional playground with a large number of fixed facilities and a natural playground with pine trees, shrubs, fallen tree trunks, a table and simple wooden benches (both sites are about $500 \mathrm{~m}^{2}$ ), and record their behaviors. The results showed that compared with the traditional playground, children used natural materials to play more kinds of games in the natural playground, the frequency of chase and hide \& seek was higher, physical activities were more active, and the time to interrupt the activities was less, especially among boys [1].

Cara Megan King McClain (2017) selected 11 children (3-5 years old, 5 boys and 6 girls) from a city kindergarten in the United States to observe their activity characteristics in a wild natural play space with fast flowing water, rugged paths and many climbing rocks, and a semi-structured natural play space with streams, bridges, plank roads, rock-climbing structures and swinging ropes. The investigation found that the two kinds of play environments both support physical behaviors such as running, jumping, climbing and falling, and children have positive reactions to the challenges and even falls. Facing the challenges in the natural environment, children focus more on tolerance and help than on competition and fighting. There are also some differences between the activities in the two natural spaces. For example, the wild space with large stones has more rock-climbing activities, while the semi-structured space with swing ropes brings more swing games. Therefore, we should encourage the provision of natural play environments with various degrees of risk to increase children's development opportunities [21].

\section{Design Points of Natural Playgrounds in Urban Parks}

According to children's physical and mental needs for play and their preference for the play space and elements, several factors that should be considered in the design of the playground can be mapped out (Table 2), so as to attract children to feel and play (this is the best way for them to develop), and further summed up 5 design points of urban park natural playgrounds.

Table 2. Children's favorite elements in play and design considerations.

\begin{tabular}{lll}
\hline & Children's psychological needs and favorite places and activities & Design considerations in playgrounds \\
\hline 1 & $\begin{array}{l}\text { Water, sand, plants and other natural scenes, wind and rain, sunshine and other } \\
\text { weather phenomena, as well as the existence of animals }\end{array}$ & Multi-sensory connection with nature, natural shape and colour \\
2 & $\begin{array}{l}\text { Large open space (grassland), running, chasing and playing in an unorganized } \\
\text { way, imagination, and gaining a sense of control }\end{array}$ & $\begin{array}{l}\text { Keeping some undesigned or unfinished space, movable } \\
\text { materials }\end{array}$ \\
3 & Simple and clear natural playing equipment with certain guidance \\
4 & Prospect and refuge to gain a sense of strength and security & Combination of natural materials and playing facilities \\
5 & Climbing, rocking elements of adventure for challenging & Various scales, from wide space to private corner \\
6 & Mysterious place for exploration interest & Allowing risk experience with no harm or low harm \\
\hline
\end{tabular}

\subsection{Pay Attention to the Accessibility and Approachability of Natural Environment}

Children's ways of experiencing nature can be divided into: (1) direct experience of contacting with pure and undisturbed outdoor natural environment such as forest, mountains and rivers; (2) indirect experience of semi-natural (artificial natural) environment controlled by human beings such as parks and zoos; (3) symbolic experience of appreciating nature from a distance through visual and other means [1].

One of the important meanings of urban parks is to create a real and perceptible natural environment in the city.
Therefore, the superior accessibility of the natural environment is the main factor, which directly determines the frequency of children's contact with nature. Secondly, the natural elements that can be directly contacted can make children get deeper natural interactive experience than those who can only be observed but not be close to [49]. In addition to providing observable symbolic experience, the natural landscape in the park needs more indirect and even direct experience that can be in it, directly contact and participate in the cultivation [50]. For example, shrubs with openings are accessible, which can lead to children's immersive experience of nature more than the flower bed 
completely enclosed by hedgerow; compared with the ornamental water surface with safety fence, the barrier free and accessible water can bring children real happiness from physical feelings. As the chairman of the Leiderdorp Dwarstuin playground said: "On the grass, we would encourage children to pick flowers. These flowers will also attract bees, which will lead birds to the playground, so that children can see what kinds of birds live here and how flowers and fruit grow!" [18]

\subsection{Let the Wild Natural Objects and the Re-Molded Natural Products Complement Each Other}

"Jungle" nature is a natural habitat full of wild interest and free growth, which can give children enough sensory stimulation and obtain a kind of restorative experience [51]. Limited to the characteristics of urban parks, there are inevitably traces of manual processing. Under limited conditions, it is better to maintain the micro wild ecosystem, simulate the original natural scene, maintain the natural growth state of plants, accommodate birds, insects and other creatures, and allow the spread of dry branches and fallen leaves, which are better presentation of the natural habitat. These make children intuitively feel the complexity of things in the real nature: each plant has its own shape, and each stone has its unique texture. In itself, it is not regular and uniform.

However, in view of the fact that urban children have long been separated from the wild nature, the purely natural environment may make them feel inaccessible or not supposed to play, because they are not "included" in the play space. The practice of separating nature from built play space may lead to children's lack of physical contact with biological factors. The research on "biophilic design" shows that the experience of "nature of the space" will be enhanced by combining "nature in the space" with "natural analogues" [52]. Furthermore, re-molded natural products increase the richness and identifiability of natural space, promote children's biological reaction, and stimulate children's creative consciousness to change things through their own activities. The research carried by Fjørtoft and Sageie (2000) found that an established playground containing natural elements within its boundary may be more able to undertake activities related to nature than a playground with separated facilities and natural elements [53]. Sargisson and McLean's tests (2012) also showed that when natural elements were integrated into the traditional standard playgrounds, the proportion of time children spent using natural elements $(17.72 \%)$ was significantly higher than that when natural elements were physically separated from play facilities $(9.55 \%)$ [54]. Therefore, it is worth encouraging to make use of the original wild natural materials, supplemented by natural materials, to form the combination of children's direct and indirect experience of nature.

Natural products generally include two aspects: (1) One is to use bamboo, wood, sand, soil and other natural materials, combined with necessary artificial materials, to process and form natural facilities [15] such as tree houses and flying wooden piles for children to carry out richer games; (2) The other is to retain the "moving/loose parts" brought by nature [55], such as fallen branches and leaves, sand and gravel, etc. if possible, certain auxiliary materials and tools can be provided to help children carry out the creative activities of "construction-eradication-reconstruction" that excite them [13]. (e. g., Figure 3)

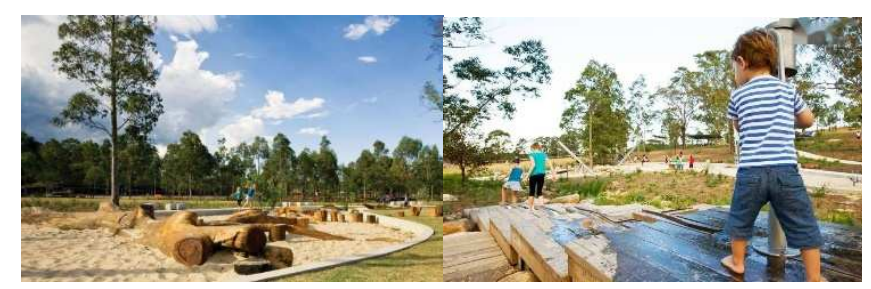

Figure 3. Nature playground in Lizard Log Park, Sydney, Australia.

\subsection{The Rugged Terrain Can Be Combined with the Flat Grassland}

Children generally like to play in the space with rich levels of change. The undulating terrain is the key factor to determine the interest of the playground, not just as an ornamental background in the park. The theory of "prospect-refuge" states that children need not only "a place with broad vision" to get the sense of "monitoring" and "planning", but also "a place to provide shelter" to obtain a solid sense of security [56]. If the two factors are brought together to provide a place for "observing the prospect without being found", then it can effectively enhance the stimulation and interaction of children's play. The concave-convex terrain and holes can fit the psychological needs of children, and naturally create an excellent place for play [11]. In addition, the changing terrain and simple auxiliary climbing facilities can stimulate more physical activities. Rushing or climbing the hillside and then sliding or running down is a kind of exciting exercise for children. (e.g., Figure 4)

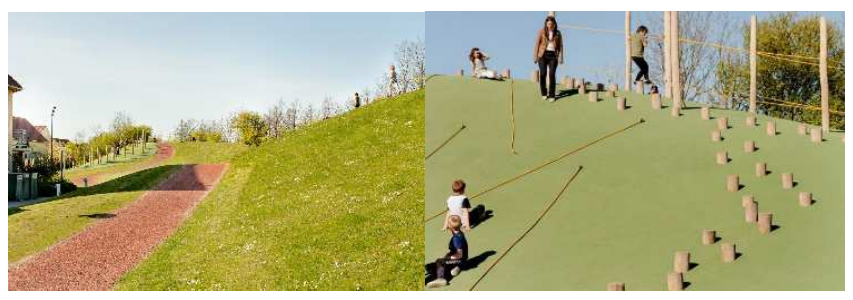

Figure 4. Activity site of Kastrup community park, Copenhagen, Denmark.

Under big trees, the open grassland with unobstructed vision and shade can also be regarded as a kind of flexible play space. Children would run and chase freely, race to climb trees, and parents can sit on the grass to watch and protect.

\subsection{Create Multi-Sensory Experience and Various Types of Play with Diverse and Dynamic Natural Elements}

The human brain connects with the outside world through the five sensory functions of vision, hearing, smell, taste and touch. The multiple experience of the combination of the five senses is a necessary way for children to experience the 
nature in an all-round way, which has a profound and lasting impact on children. In the design of playgrounds, people often focus more on the creation of visual feeling. It is true that vision is an important way for people to obtain information, and the presentation of natural form and color is an effective way to obtain biological affinity, but "high-quality play" is always accompanied by a more comprehensive sensory experience. It is found that the impact of sound landscape on people's mental health is stronger than that of visual landscape [57]; olfactory sense is more capable of recalling and remembering than any other feeling, but unfortunately, we seldom use it [58]; taste is also a physiological feeling that can keep people's impression for a long time; touch brings real body perception and directly realizes the nature of things. Different natural elements have different sensory emphases. For example, sand feels soft, can ease the mood; stone texture is hard, resistant to fall; fruit trees fragrance, can be picked and eaten, etc. All these bring rich fun. A good natural play space is also a "sensorial garden". Using the principle of "non-visual connection with nature" [59], creating space to encourage multiple sensory stimulation is the upper value of an urban park.

The discovery that "the diversity of natural elements seems to be more important than the size of green space" is an inspiration for urban parks with limited space [54]. The results show that there is a positive correlation between the diversity of vegetation types and children's play activities [53]. In places with greater diversity of natural elements, children spend more time in contact with natural elements. This may be because the higher level of diversity in the environment can better meet children's exploration needs and adapt to sport, social, creative, sensory and other forms of play [60]. It is also an advantage of natural playgrounds compared with artificial playgrounds. Making sure that the play space contains a series of natural elements will easily make up for the lack of size.

Children are changeable. Accordingly, children's playgrounds should be dynamic. On the one hand, it is the active attribute of natural elements. For example, the flowing water brings visual, auditory and tactile impact, which is more popular with children than static water and has purification effect on air [49]; vegetation and grassland that attract butterflies and insects often attract children. On the other hand, many natural elements are affected by changes in time, climate and season, thus providing continuous diversity and different sensory experiences. For example, some animals show special activities before the rain, many kinds of plants and flowers show different appearance and smell in the four seasons of the year, etc. "Eco-Revelatory" design is to focus on the changes of these natural states, and magnify them to show the traces left by natural processes [61].

\subsection{Balance Necessary Security with Controllable Risk Taking}

"Risky play" is an "exciting form of play involving uncertainty", including approaching or using vulnerable elements or tools, rough rollover games, high-speed or high-altitude games and games that may get lost [48]. Research shows that risk-taking activities are positively correlated with physical skills, mental health, independent judgment and risk management ability, which provide children with health and development benefits that other activities cannot achieve [62]. And there's little evidence that dangerous games increase the risk of injury [63], and by letting kids try, they have a stronger sense of their own safety. The natural playground is the first choice for children to carry out adventure games. The natural open environment and non-standard natural facilities bring unrestricted play environment for children to explore and shape freely [64]. At the same time, strong branches of trees, steep rocks, streams, scattered logs, swinging ropes, mud pits, bricks and other natural adventure elements can be used for children to climb, hang, jump up and down, balance walk, leap and other challenging activities. (e. g., Figure 5)

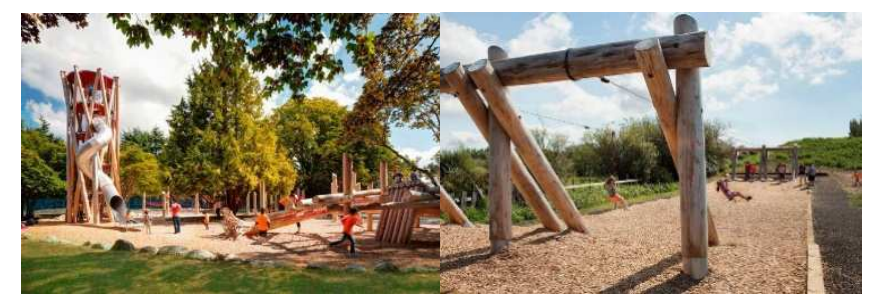

Figure 5. Terra Nova children's playground, Richmond, Canada.

Although risky play is advocated, it should also be within the controllable range, with challenges but without serious damage. That is, natural playgrounds must ensure the necessary safety, so that children can embrace risks within the safe boundary [16]. For example, in the planning and design, the buffer distance between elements should be kept to avoid unnecessary interference and collision between different activities; the maximum height of falling should be limited in high-altitude games, and soft materials such as soil, fine sand or leaves need to be laid; the depth of water and sand should be controlled and the quality should be monitored. In daily management, the facilities should be checked regularly; and administrators who pay close attention to children's activities are required within the emergency rescue distance, so as to stop the behaviors that may cause serious injuries quickly, but do not interfere too much in children's normal challenging activities [65].

For natural playgrounds, the balance between providing a natural environment that excites children and the desire to protect them can be a complex and long-term struggle. How to find the right balance point to make children, parents and professionals feel happy is a question to be explored [18]. But in any case, creating conditions to encourage children's risk-taking spirit and enhance their self-protection ability should be one of the directions of natural playgrounds in urban parks.

\section{Conclusion and Prospect}

\subsection{Research Conclusion}

Childhood experience is of great significance to one's life. 
Play and nature are closely linked to children's physical and mental health. Playing in the natural environment has left a deep memory for people. With the disappearance of natural play space, children's health problems emerge in endlessly. People gradually realize the importance of integrating nature into children's outdoor playgrounds, and carry out research and design practice. A built environment can never replace the relationship between children and nature, but it can support the understanding of nature by providing children with activities to explore nature. Urban park is part of the outdoor play space for children with public and open attributes, which not only needs the pursuit of "quantity", but also the main task to improve the quality of its playground. It should provide children with a play space in close contact with nature. The natural play field tries to take a step back and provide a compromise between the traditional equipment playground and the nostalgic "wilderness" play space: a semi-structured playground close to nature, relatively safe and moderately risky in the 21 st century. There, children can re-interact with the natural environment in an interesting way, enabling them to be "children", but not completely "free-range parenting". Based on this, combined with children's physical development, psychological characteristics, cognitive ability and activity representation, 5 points of thinking on the planning and design of urban park natural playgrounds are summarized, in order to benefit the research in related fields (Figure 6).

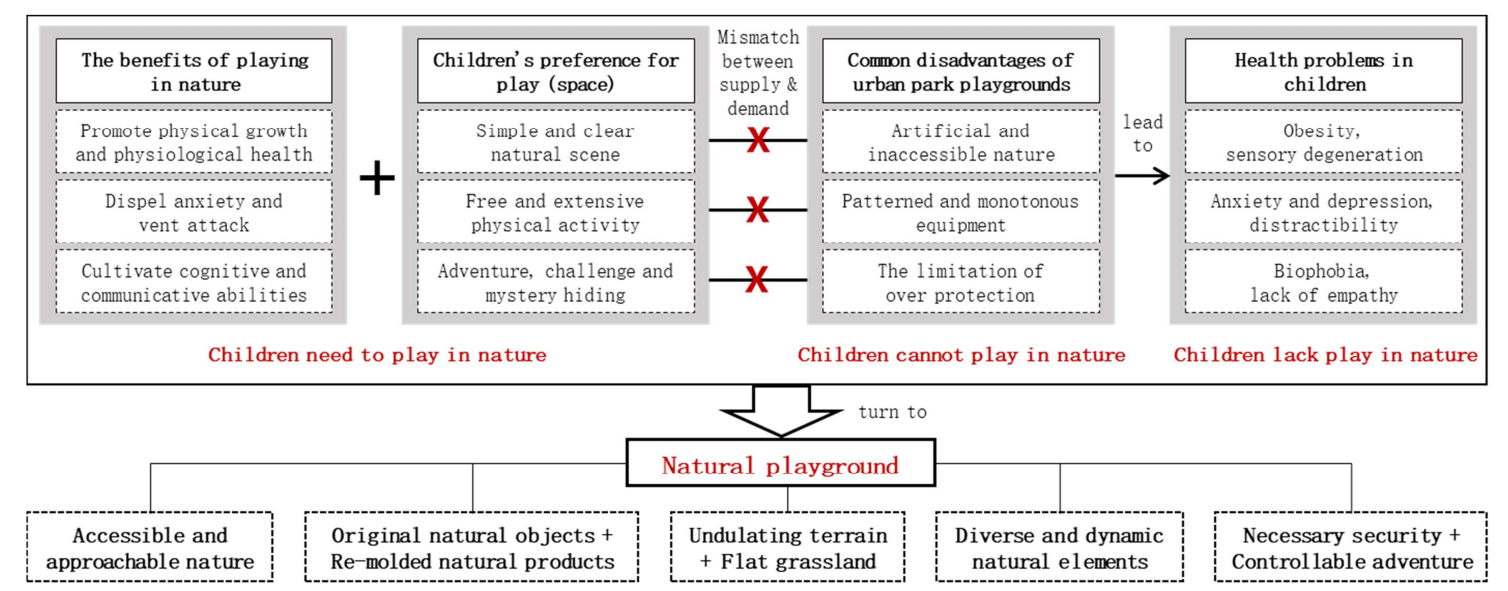

Figure 6. The logic diagram of naturalization turning of playgrounds in urban parks.

\subsection{Future Prospect}

It is necessary to conduct further research on children's choice priority, use mode and feeling evaluation of play space and elements, so as to guide planning and design accurately in the future. At present, what is relatively lacking is to measure children's use of elements when all kinds of natural and artificial play opportunities are basically the same. For the research on children's behavior in playgrounds, many scholars have investigated children's behaviors in artificial or natural play environments [1], but only a small number of studies directly judge children's activities when various opportunities exist. Plus, these studies focus on the total statistics [4], while the comparative studies on children's choice priority and diverse elements' play time are even less. We can track individual children's behavior in the whole play process to determine which elements children prefer to play, and record their time allocated on different elements, supplemented by interviews of their feelings [54], so as to explore children's demand for play elements and the reasons.

The promotion of children's play in nature needs the joint efforts of all sectors of society. For the spaces that are beneficial to children's health, the natural playground in urban parks is only one aspect. The whole park, community, street and even the public places of the entire city can make a difference. Child is an essential concern of a family. A city conducive to the healthy growth of children has a strong attraction to the whole family. The natural place cannot only provide a more healthful living environment for children, but also for all members of the society, and promote the realization of national health in a certain sense. As Louv points out in his book Childhood's Future, "by rethinking how our cities treat children, we rethink how we all want to live" [66].

\section{Acknowledgements}

This paper relies on the exploration of building a child-friendly city in Shenzhen and is supported by Foundation of Guangdong Soft Science Research Project (Project No.: 2019A101002046). We would like to thank the Child-Friendly City Research Centre of Urban Planning \& Design Institute of Shenzhen for its support, especially for the inspiration, guidance and suggestions of the director Lei Liu and the engineer Yuechang Lei. At the same time, thanks to our colleagues Lichan Zhou and Jiayue Wang for their sincere assistance.

\section{References}

[1] Torkar, G., \& Rejc, A. (2017). Children's play and physical activity in traditional and forest (natural) playgrounds. International Journal of Educational Methodology, 3 (1), 25-30. 
[2] World Health Organization. (2020). Improving early childhood development: WHO guideline. Geneva, Switzerland: WHO.

[3] Pyle, R. (2002). Eden in a vacant lot: Special places, species and kids in community of life. In P. H. Kahn, \& S. R. Kellert (Eds.), Children and nature: Psychological, sociocultural and evolutionary investigations (pp. 305-327). Cambridge, MA, USA: MIT Press.

[4] Dan, Z. X. (2018). Study on the design of children pleasure space in urban parks-Take main district of Chongqing as an example. M. A. Dissertation, Chongqing University, Chongqing, China.

[5] Solomon, S. G., \& Zhang, W. Y. (2007). Changes in American playgrounds 1966-2006. Chinese Landscape Architecture, 10, 15-18.

[6] Pan, Y. L. (2017). Freedom, captivity and binding-The change of play space and children's physical situation. Contemporary Education Sciences, 12, 9-12+8.

[7] Louv, R. (2005). Last child in the woods: Saving our children from nature-deficit disorder. Chapel Hill, NC, USA: Algonquin Books.

[8] Kellert, S. R., \& Wilson, E. O. (1993). The biophilia hypothesis Washington DC, USA: Island Press.

[9] Wang, X., Chen, T. T., \& Lin, G. S. (2020). Study on the application of natural elements in urban parks' children's play space in China. Urban Planning International, 1-14. Retrieved October 21, 2020, from http://kns.cnki.net/kcms/detail/11.5583.TU.2020082 5.1655.008.html.

[10] United Nations International Children's Emergency Fund. (1989). Convention on the rights of the child. Retrieved October 21, 2020, from https://www.unicef.org/child-rightsconvention/convention-text.

[11] Bao, L. Q. (2013). Naturalizing design of children's outdoor playgrounds. Journal of Chinese Urban Forestry, 11 (3), 38-40.

[12] Li, L., \& Yang, L. (2020). Discussion on hot topics of landscape architecture focusing on public health in the post-epidemic era. Landscape Architecture, 27 (9), 10-16.

[13] Tan, M. L., \& Zhou, F. C. (2008). Parks \& gardens fit for children-Design and research of user-friendly park. Chinese Landscape Architecture, 9, 43-48.

[14] Luo, Y. Y., \& Wang, X. (2017). Research on children playground of natural style in urban outdoor space based on landscape perception. Landscape Architecture, 3, 73-78.

[15] Shi, H. H. (2016). The study of natural interactive children's recreational space on the city park. M. A. Dissertation, Southwest Jiaotong University, Chengdu, China.

[16] Tang, L. Y. (2018). Natural children's recreational space design in urban neighborhood park. Huazhong Architecture, 36 (7), 40-42.

[17] Berry, T. (2020). Exploring access to nature play in urban parks: resilience, sustainability, and early childhood. Sustainability, 12 (12), 4894-4911.

[18] Verstrate, L., \& Karsten, L. (2016). Development of nature playgrounds from the 1970 s onwards. In B. Evans, J. Horton, \& T. Skelton (Eds.), Play and recreation, health and wellbeing (pp. 173-191). Singapore: Springer.
[19] Johnson, J. M., \& Hurley, J. A. (2002). A future ecology of urban parks: reconnecting nature and community in the landscape of children. Landscape Journal, 21 (1), 110-115.

[20] Zhou, X. L., \& Xiao, Y. (2019). Application of situational natural experience in landscape design of children's outdoor activity spaces: A case study of Jinshanling Pinecone Theme Park. Landscape Architecture, 26 (10), 72-77.

[21] McClain, C. (2017). Social contexts of development in natural outdoor environments: Children's motor activities, personal challenges and peer interactions at the river and the creek. M. A. Dissertation, The University of Tennessee, Knoxville, USA.

[22] Gill, T. (2014). The benefits of children's engagement with nature: A systematic literature review. Children, Youth \& Environments, 24 (2), 10-34.

[23] Maller, C., Townsend, M., Pryor, A., Brown, P., \& Lawrence, S. L. (2006). Healthy nature healthy people: 'Contact with nature' as an upstream health promotion intervention for populations. Health Promotion International, 21 (1), 45-54.

[24] Louv, R. (2012). The new nature movement-Going beyond environmentalism and sustainability. Landscape Architecture Frontiers, 22 (2), 78-81.

[25] Bowler, D. E., Buyung-Ali, L. M., Knight, T. M., \& Pullin, A. S (2010). A systematic review of evidence for the added benefits to health of exposure to natural environments. BMC Public Health, 10 (1), 456-465.

[26] Hua, A. H. (1998). The theory of children's play. Shanghai, China: Shanghai Education Press.

[27] Freud, S. (1957). The standard edition of the complete psychological works of Sigmund Freud (J. Strachey, Trans.). London, UK: Hogarth Press. (Original work published 1915)

[28] Piaget, J., \& Inhelder, B. (1969). The psychology of the child. New York, USA: Basic Books.

[29] Louv, R. (2011). The nature principle: Reconnecting with life in a virtual age. Chapel Hill, NC, USA: Algonquin Books.

[30] Lowry, C. A., Smith, D. G., Siebler, P. H., Schmidt, D., Stamper, C. E., \& Hassell, J. E., et al. (2016). The microbiota, immunoregulation, and mental health: implications for public health. Current Environmental Health Reports, 3 (3), 270-286.

[31] Kuo, M. (2015). How might contact with nature promote human health? Promising mechanisms and a possible central pathway. Frontiers in Psychology, 6, 1093-1100.

[32] White, R. (2004). Benefits for children of play in nature. Kansas City, USA: White Hutchinson Leisure\& Learning Group.

[33] Fjørtoft, I. (2004). Landscape as playscape: The effects of natural environments on children's play and motor development. Children, Youth \& Environments, 14 (2), 21-44.

[34] Erikson, E. H. (1993). Childhood and society. New York, USA: W. W. Norton \& Company.

[35] Winnicott, D. W. (1971). Playing and reality. New York, USA: Basic Books.

[36] Ulrich, R. S., Simons, R. F., Losito, B. D., Fiorito, E., \& Zelson, M. (1991). Stress recovery during exposure to natural and urban environments. Journal of Environmental Psychology, 11 (3), 201-230. 
[37] Kuo, F. E., \& Sullivan, W. C. (2001). Aggression and violence in the inner city: Effects of environment via mental fatigue. Environment \& Behavior, 33 (4), 543-571.

[38] Kaplan, R., \& Kaplan, S. (1989). The experience of nature: A psychological perspective. Cambridge, UK: Cambridge University Press.

[39] Taylor, A. F., Wiley, A., Kuo, F. E., \& Sullivan, W. C. (1998). Growing up in the inner city green spaces as places to grow. Environment \& Behavior, 30 (1), 3-27.

[40] Barbour, A. C. (1999). The impact of playground design on the play behaviors of children with differing levels of physical competence. Early Childhood Research Quarterly, 14 (1), 75-98.

[41] Woolley, H., \& Lowe, A. (2013). Exploring the relationship between design approach and play value of outdoor play spaces. Landscape Research, 38 (1), 53-74.

[42] Pirkko, H., \& Marjaana, K. (2007). From bogey mountains to funny houses: Children's desires for play environment. Australian Journal of Early Childhood, 32 (3), 39-47.

[43] Wang, Y. X., \& Gao, W. X. (2019). Strategies for enhancing children's friendship in park playgrounds: Taking Shenzhen Honey Park as an example. Design Community, 6, 54-61.

[44] Veitch, J., Flowers, E., Ball, K., Deforche, B., \& Timperio, A. (2020). Exploring children's views on important park features: A qualitative study using walk-along interviews. International Journal of Environmental Research and Public Health, 17 (13), 4625-4638.

[45] Smith, S. J. (1998). Risk and our pedagogical relation to children: On the playground and beyond. New York, USA: State University of New York Press.

[46] Wang, X., \& Liu, X. Y. (2015). The design of natural style playground-A case study of a primary school in the UK. Chinese Landscape Architecture, 31 (1), 46-50.

[47] Peterson, Y. (2012). 'Over stock and stone': A design proposal for a nature playground in the recreation area of Skrylle. M. A. Dissertation, Swedish University of Agricultural Sciences, Uppsala, Sweden.

[48] Sandseter, E. B. H. (2009). Affordances for risky play in preschool: The importance of features in the play environment. Early Childhood Education Journal, 36 (5), 439-446.

[49] Zhou, Y. T. (2016). Research on natural children activity space design of urban park. M. A. Dissertation, Southwest Jiaotong University, Chengdu, China.

[50] Jiang, B. (2020). Urban natural landscape and citizens' mental health: Key issues. Landscape Architecture, 27 (9), 17-23.

[51] Frost, J. L. (2010). A history of children's play and play environments: Toward a contemporary child-saving movement. New York, USA: Routledge.

[52] Browning, W. D., Ryan, C. O., \& Clancy, J. O. (2014). 14 Patterns of biophilic design: In improving health \& well-being in the built environment. New York, USA: Terrapin Bright Green LLC.

[53] Fjørtoft, I., \& Sageie, J. (2000). The natural environment as a playground for children: landscape description and analyses of a natural playscape. Landscape \& Urban Planning, 48 (1-2), 83-97.

[54] Sargisson, R. J., \& Mclean, I. G. (2012). Children's use of nature in New Zealand playgrounds. Children, Youth \& Environments, 22 (2), 144-163.

[55] White, R., \& Stoecklin, V. (1998). Children's outdoor play \& learning environments: Returning to nature. Early Childhood News, 10 (2), 24-30.

[56] Appleton, J. (1996). The experience of landscape. New York, USA: John Wiley.

[57] Ma, H., \& Shu, S. (2018). An experimental study: The restorative effect of soundscape elements in a simulated open-plan office. Acta Acustica United with Acustica, 104 (1), 106-115.

[58] Vaz, N. (2013). Montessori special education and nature's playground. Namta Journal, 38 (1), 71-79.

[59] Priscila, G. I. (2017). Biophilic playspace design: Bringing together children and nature in urban Honolulu. Doctorial Dissertation, University of Hawaii at Manoa, Honolulu, USA.

[60] Moore, R. C., \& Cosco, N. G. (2007). What makes a park inclusive and universally designed? A multi-method approach. In C. W. Thompson, \& P. Travlou (Eds.), Open space: People space (pp. 85-110). London, UK: Taylor \& Francis.

[61] Brown, B., Harkness, T., \& Johnston, D. (1998). Eco-revelatory design: Nature constructed/nature revealed. Landscape Journal, 17 (Special Issue), $\mathrm{x}$-xi.

[62] Lavrysen, A., Bertrands, E., Leyssen, L., Smets, L., \& Graef, P. D. (2015). Risky-play at school. Facilitating risk perception and competence in young children. European Early Childhood Education Research Journal, 25 (1), 89-105.

[63] Brussoni, M., Gibbons, R., Gray, C., Ishikawa, T., Sandseter, E., \& Bienenstock, A., et al. (2015). What is the relationship between risky outdoor play and health in children? A systematic review. International Journal of Environmental Research \& Public Health, 12 (3), 6423-6454.

[64] Shen, Y., Liu, S., \& Zhao, M. X. (2020). The origin, examples and enlightenment of adventure playground. Urban Planning International, 1-15. Retrieved October 21, 2020, from http://kns.cnki.net/kcms/detail/11.5583.tu.20200831.1756.006. html.

[65] Dong, W., Yan, H. Z., \& Dong, Y. (2020). Growing up through play: Experience of creating children's play environments in the UK. Shanghai Urban Planning Review, 3, 14-19+37.

[66] Louv, R. (1990). Childhood's future. Boston, USA: Houghton Mifflin. 